\title{
Feed transition in larval rearing of bocudo, Steindachneridion scripta (Pisces, Pimelodidae), using Artemia spp. nauplii and artificial diet
} \author{
náuplios de Artemia spp. e dieta artificial]

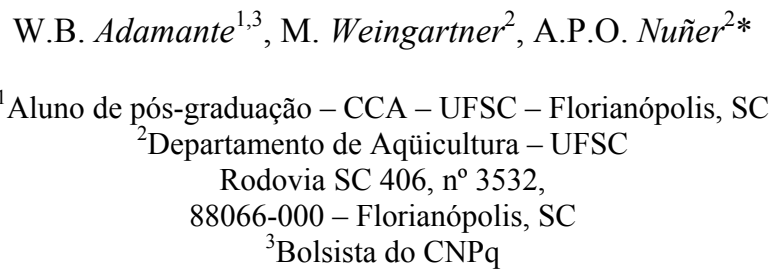

[Transição alimentar na larvicultura do bocudo, Steindachneridion scripta (Pisces, Pimelodidae), com o uso de

\begin{abstract}
Feed transition of Steindachneridion scripta larvae was investigated using seven treatments in which the reference diet, Artemia spp. nauplii, was totally substituted for a 56\% crude protein artificial diet in twoday intervals. Initially, all treatments were fed with Artemia spp. nauplii and, subsequently, during the transition period, feed was equally composed by Artemia sp. nauplii and artificial diet. Everyday, one of the treatments began the feed transition, which was implemented between the second and the eighth days of culturing. Two treatments were used as control: one exclusively fed Artemia spp. nauplii and another only with artificial diet. Total weight, total length, and survival rate were not influenced by the day in which feed transition was implemented $(\mathrm{P}>0.05)$, and their mean values $( \pm \mathrm{SD})$ were $31.1 \pm 25.0 \mathrm{mg}$, $13.3 \pm 1.5 \mathrm{~mm}$ and $58.8 \pm 12.0 \%$, respectively. This suggests that Steindachneridion scripta larvae adapted well the transition to artificial diet.
\end{abstract}

Keywords: bocudo, Steindachneridion scripta, feed transition, larval feeding

\section{RESUMO}

A transição alimentar de larvas de Steindachneridion scripta foi investigada utilizando-se sete tratamentos, nos quais a dieta básica, composta por náuplios de Artemia spp., foi integralmente substituída, em intervalo de dois dias, por uma dieta artificial contendo $56 \%$ de proteína bruta. Inicialmente, todos os tratamentos receberam náuplios de Artemia spp. No periodo de transição alimentar, metade da alimentação foi formada por náuplios de Artemia spp. e metade por dieta artificial. A cada dia, um dos tratamentos entrou na fase de transição, que foi implementada entre o segundo e $o$ oitavo dia de cultivo. Utilizaram-se dois tratamentos como controle; em um as larvas foram alimentadas, exclusivamente, com náuplios de Artemia spp. e em outro, somente, com dieta artificial. Peso total, comprimento total e sobrevivência não foram influenciados pelo dia de implantação da transição

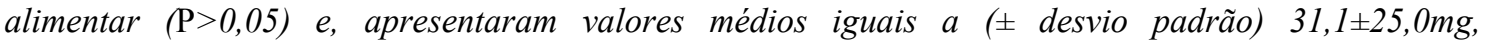
$13,3 \pm 1,5 \mathrm{~mm}$ e $58,8 \pm 12,0 \%$, respectivamente, sugerindo que as larvas Steindachneridion scripta aceitaram bem a transição alimentar para a dieta artificial.

Palavras-chave: bocudo, Steindachneridion scripta, transição alimentar, alimentação de larvas

Recebido em 30 de agosto de 2005

Aceito em 21 de agosto de 2007

*Autor para correspondência (Corresponding author)

E-mail: apon@cca.ufsc.br 


\section{INTRODUCTION}

A feeding strategy often adopted in fish larval rearing consists in offering live prey to the larvae (Sipaúba-Tavares and Rocha, 2003). Live prey could be, for example, foraging larvae or zooplankton, whose use will depend on the adequate size of fish larvae and also on its availability.

Feeding with live prey is extremely important because larvae of several fish species do not present a completely developed digestory tract in the first days of life, i. e., they do not have the enzymes required to digest artificial diets (Zavala-Camin, 1996; Sipaúba-Tavares and Rocha, 2003). Furthermore, live prey promotes visual stimulus (Ortega, 2000), which increases feeding by predatory larvae, thus reducing cannibalism in some species and enhancing larval production.

Hogendoorn (1980) and Knud-Hansen et al. (1990) reported the successful use of live or frozen zooplankton as feed in larval rearing of Clarias gariepinus and Clarias batrachus, respectively. Among zooplankton species, cladocerans of the genus Moina were successfully used in larval rearing of Chanos chanos (Villegas, 1990) and Clarias macrocephalus (Fermin and Bolivar, 1991).

Despite the availability of wild zooplankton, the use of Artemia spp. nauplii as feed in the larval rearing of marine or freshwater fish has become common and widely practiced (Kurunuma and Fukusho, 1984; Lavens and Sorgeloos, 1996; Kolkovsky et al., 1997) because it is readily available in the market and practical to use.

Nevertheless, in spite of the advantages, the use of Artemia nauplii increases the cost of production. Thus, in order to reduce such costs and provide economic return, fish larvae should be fed Artemia nauplii for a period as short as possible.

Although good results have been achieved with live prey during larviculture, some freshwater fish larvae can be successfully reared exclusively with artificial diet since the first feeding, as reported for C. gariepinus (Uys and Hecht, 1985; Appelbaum and Van Damme, 1988), Coregonus spp. (Bergot et al., 1986; Dabrowski et al., 1986) and Cyprinus carpio (Bergot, 1986; Charlon et al., 1986 apud Kerdechuen and Legendre, 1994).

However, for carnivorous species such as bocudo, Steindachneridion scripta (Miranda Ribeiro, 1918), that presents cannibalism during larviculture, feed transition strategies have been successfully practiced, as in the case of pintado, Pseudoplatystoma spp. (Machado et al., 1998; Smerman et al., 2002), and tucunaré, Cichla spp. (Cyrino and Kubitza, 2003). Feed transition period usually consists in initially providing zooplankton, foraging larvae or ground meat (fish fillet, cattle heart etc.) and, gradually, replacing it with artificial diet.

Transition period aims at avoiding that a sudden change in feeding causes cannibalism among larvae or impairment of growth and survival rates at the end of the larviculture. S. scripta species is native from Prata basin (Ringuelet et al., 1967), and in the Uruguay River it is important for local fisheries (Meurer e Zaniboni Filho, 2000).

The objective of the present study was to assess different feed transition periods for S. scripta, gradually replacing live food to artificial diet in order to enhance larviculture.

\section{MATERIAL AND METHODS}

Bocudo larvae hatched in the laboratory after induced spawning that followed the protocol described by Zaniboni Filho and Barbosa (1996).Larvae were kept in cylindroconical incubators until the final absorption of the vitellus. Then, larvae of the same bulk, with mean weight and length of $7.7 \pm 1.4 \mathrm{mg}$ and $8.6 \pm 0.42 \mathrm{~mm}$, respectively, were randomly transferred to $4-\mathrm{L}$ water round plastic aquaria and stocked at a density of 10 larvae/l. Aquaria were kept inside 1000-L fiber tanks in a waterbath system supplied with heaters, to minimize temperature variation.

The experimental design was composed of nine treatments with three replicates, totalizing 27 experimental units, which were randomly distributed in three blocks. Seven of the nine treatments were used to assess the best period to begin feeding transition and two were used as control, one receiving only artificial diet (control 
1) and the other fed Artemia spp. nauplii (control

2) throughout the experimental period.

On the first day of larval rearing, all experimental units received Artemia spp. nauplii at a rate of 100 nauplii/larvae/day, except control 1 , that received $5 \mathrm{~g}$ /day of a $56 \%$ ground crude protein commercial diet. Feed was offered at $8 \mathrm{am}, 4 \mathrm{pm}$ and $12 \mathrm{pm}$. Until the beginning of the feed transition period, experimental units were fed Artemia spp. nauplii, in each treatment, at the same rate as the first day.

From the second day of larval rearing onward, feed transition was implemented in different experimental units, which received transition management between the second and eighth day of culturing (Table 1). During the feed transition period, larvae were fed a diet of 50\% Artemia spp. nauplii and $50 \%$ artificial diet for two days.

Table 1. Feeding strategy adopted in the treatments to start feeding transition (FT) of bocudo larvae

\begin{tabular}{lccccccccccc}
\hline \multirow{2}{*}{ Treatment } & \multicolumn{10}{c}{ Feeding } & \multicolumn{1}{c}{ strategy } \\
\cline { 2 - 10 } & 0 & 1 & 2 & 3 & 4 & 5 & 6 & 7 & 8 & 9 \\
\hline $2^{\text {nd }}$ day & AN & AN & FT & FT & AD & AD & AD & AD & AD & AD \\
$3^{\text {rd }}$ day & AN & AN & AN & FT & FT & AD & AD & AD & AD & AD \\
$4^{\text {th }}$ day & AN & AN & AN & AN & FT & FT & AD & AD & AD & AD \\
$5^{\text {th }}$ day & AN & AN & AN & AN & AN & FT & FT & AD & AD & AD \\
$6^{\text {th }}$ day & AN & AN & AN & AN & AN & AN & FT & FT & AD & AD \\
$7^{\text {th }}$ day & AN & AN & AN & AN & AN & AN & AN & FT & FT & AD \\
$8^{\text {th }}$ day & AN & AN & AN & AN & AN & AN & AN & AN & FT & FT \\
Artemia spp. nauplii (AN) & AN & AN & AN & AN & AN & AN & AN & AN & AN & AN \\
Artificial diet (AD) & AD & AD & AD & AD & AD & AD & AD & AD & AD & AD \\
\hline
\end{tabular}

AN (Artemia nauplii); AD (artificial diet).

Following transition, larvae received $5 \mathrm{~g}$ /day of artificial diet, the same amount offered to control 1 throughout the experiment. Artemia spp. cysts were daily incubated to hatch in two periods and, for this reason, only newly hatched Artemia spp. were used.

The protocol described by Lavens and Sorgeloos (1996) was used for cyst hatchering. Salinity in the experimental units was $1.0 \%$ to allow higher Artemia nauplii survival and also more time for bocudo larvae to feed without reduction in survival, since Schütz et al. (2000) observed lower survival during bocudo larval rearing only when larvae were kept in salinity equal or above 2.0\%o. All experimental units were daily siphoned to remove debris and also half of the water volume was replaced. Water temperature, dissolved oxygen concentration and $\mathrm{pH}$ were measured twice a day, in the morning and in the afternoon, using digital oxymeter YSI- $55^{1}$ and pHmeter YSI-60 ${ }^{1}$, respectively, and total ammonia and nitrite concentrations were measured once a day, using the colorimetric method. These variables were daily analyzed, in the morning and afternoon.

${ }^{1}$ YSI Incorporated, Yellow Springs, OH, USA.
No-ionized ammonia $\left(\mathrm{NH}_{3}\right)$ in the water was calculated from total ammonia according to $\mathrm{pH}$, temperature and salinity, using the equation proposed by Johansson and Wedborg (1980), as follows: $\% \mathrm{NH}_{3}=100 /\left[1+10^{(\log K-\mathrm{pH})}\right]$, with $\log K_{1}=-0.467+0.00113 S+2,887.9 / T$, in which $K_{1}$ is the dissociation constant, $S(\mathrm{~g} / \mathrm{l})$ the salinity, and $T$ the temperature $\left({ }^{\circ} \mathrm{K}\right)$.

At the end of the experiment, all remained larvae were counted and their length and weight were measured. Data on water quality variables, mean total length and weight and survival rates were analyzed by ANOVA $(\alpha=0.05)$ and Tukey test (Zar, 1996).

\section{RESULTS AND DISCUSSION}

Throughout the experiment, mean values ( \pm standard deviation) of water temperature $\left(24.9 \pm 1.4^{\circ} \mathrm{C}\right)$, dissolved oxygen concentration $(7.2 \pm 0.4 \mathrm{mg} / \mathrm{l})$ and $\mathrm{pH}(7.8 \pm 0.1)$ were similar $(\mathrm{P}>0.05)$ among the treatments (Fig. 1).

All water quality variables were within the comfort limits for subtropical fish species (Sipaúba-Tavares, 1994; Vinatea, 1997; Luz and Zaniboni Filho, 2000; Feiden et al., 2001; Barcelos et al., 2004; Weingartner and Zaniboni Filho, 2004). 
A)

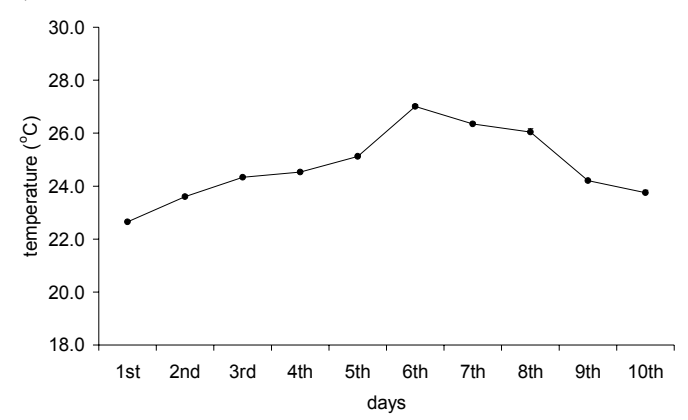

B)

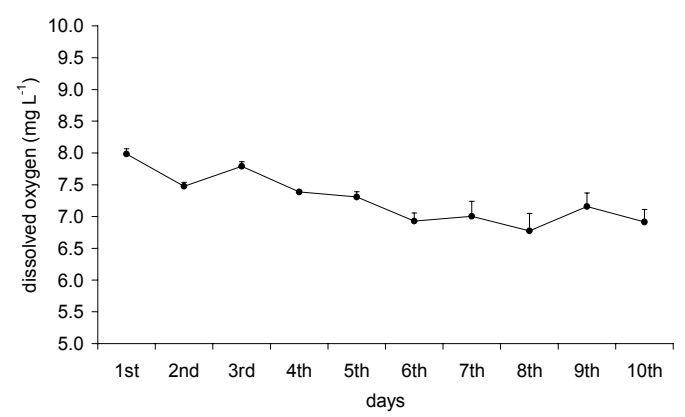

C)

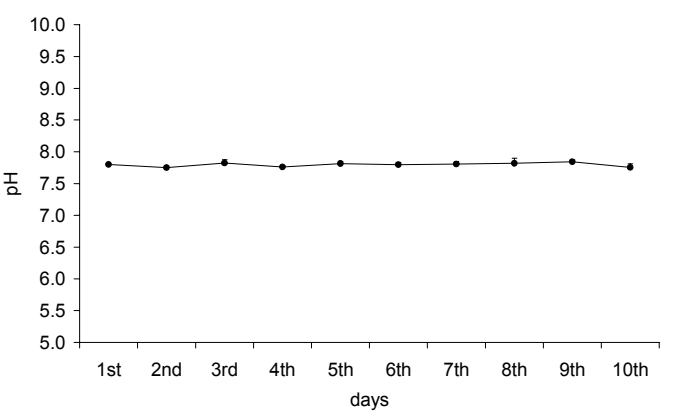

Figure 1. Mean ( \pm standard deviation) temperature (A), dissolved oxygen concentration (B) and $\mathrm{pH}(\mathrm{C})$ for all treatments during the experiment.

Non-ionized ammonia $\left(\mathrm{NH}_{3}\right)$ and nitrite $\left(\mathrm{NO}_{2}{ }^{-}\right)$ levels in water (Fig. 2) remained within acceptable levels for most of fish species and did not reach critical values (Boyd, 1979; Badisserotto, 2002) for the time of exposure used. In general, water $\mathrm{NH}_{3}$ concentrations tended to accumulate (Fig. 2) in treatments with earlier feed transition and in AD treatment. This is probably due to the decay of uneaten artificial diets, which also contributed to the increase of the water nitrite concentration.
A)

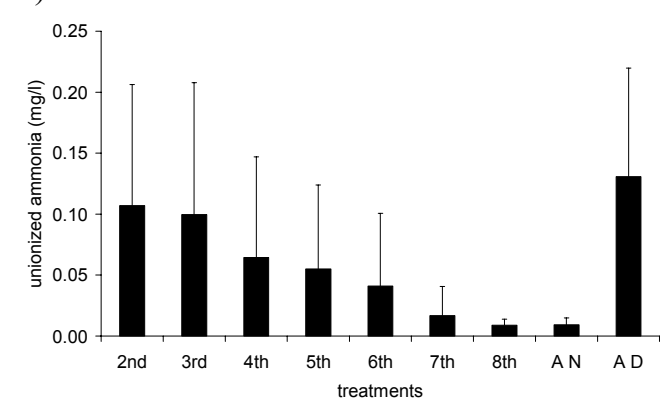

B)

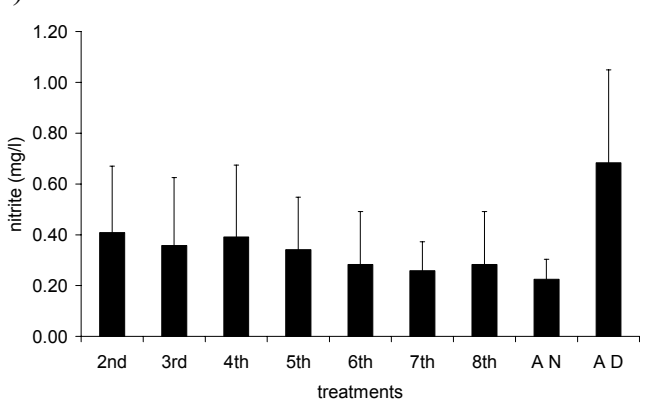

Figure 2. Mean ( \pm standard deviation) concentration of unionized ammonia (A) and nitrite (B) in each treatment.

Mean values ( \pm standard deviation) of total weight and length, and survival rate were of $31.1 \pm 25.0 \mathrm{mg}, \quad 13.3 \pm 1.5 \mathrm{~mm}$ and $58.8 \pm 12.0 \%$, respectively, which were similar $(\mathrm{P}>0.05)$ (Table 2). Kerdechuen and Legendre (1994) tested different feeds during larval rearing of African catfish, Heterobranchus longifilis, such as live zooplankton, frozen zooplankton and commercial artificial diet, and observed that total weight and survival rates were significantly lower when fed artificial diet.

Final length and weight were inversely related to survival (Fig. 3), showing the influence of density on fish growth. Comparing larval performance of four Coregonus species fed zooplankton and commercial diet, Luczynski et al. (1986) reported that the survival rate of the treatment that used zooplankton as feed was similar to treatment that used artificial diet, however, weight and length, at the end of the experiment, showed better results for zooplankton. 
Table 2. Mean values ( \pm standard deviation) of initial and final weight, total length and survival rate of bocudo larvae

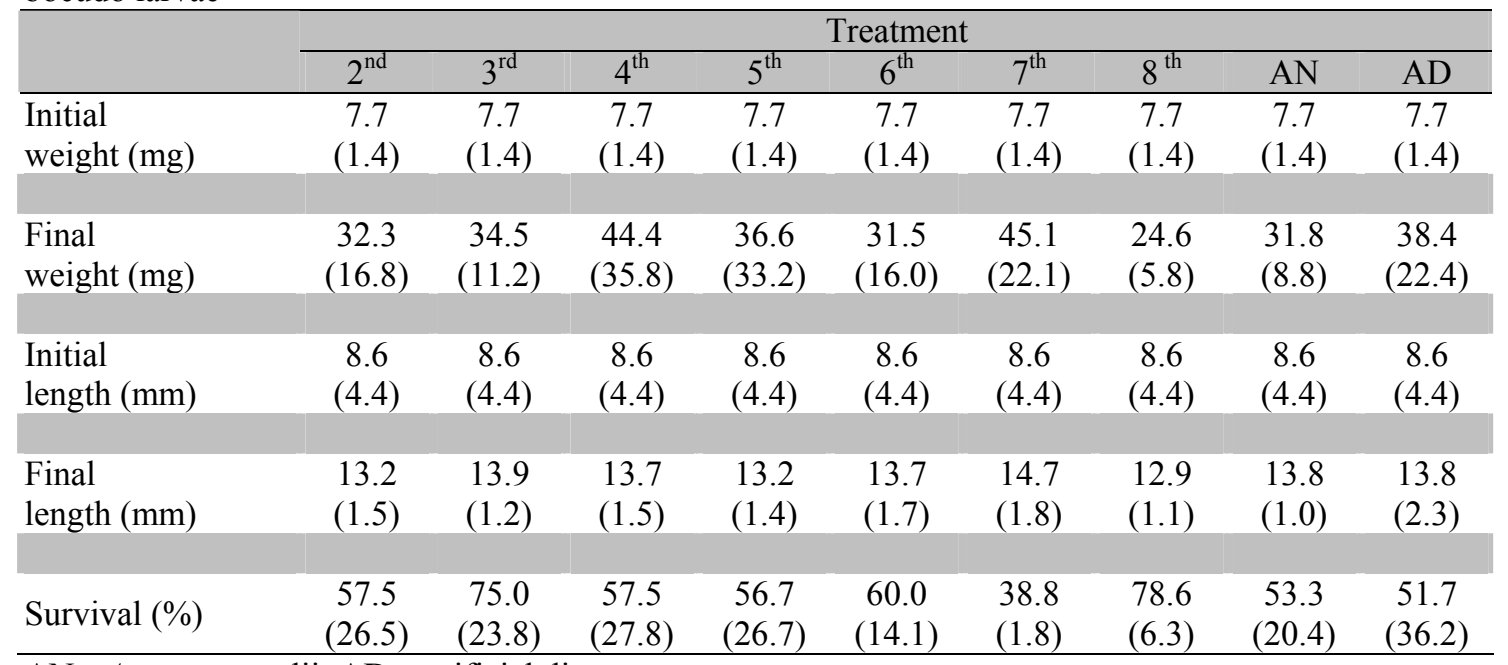

$\mathrm{AN}=$ Artemia nauplii; $\mathrm{AD}=$ artificial diet.

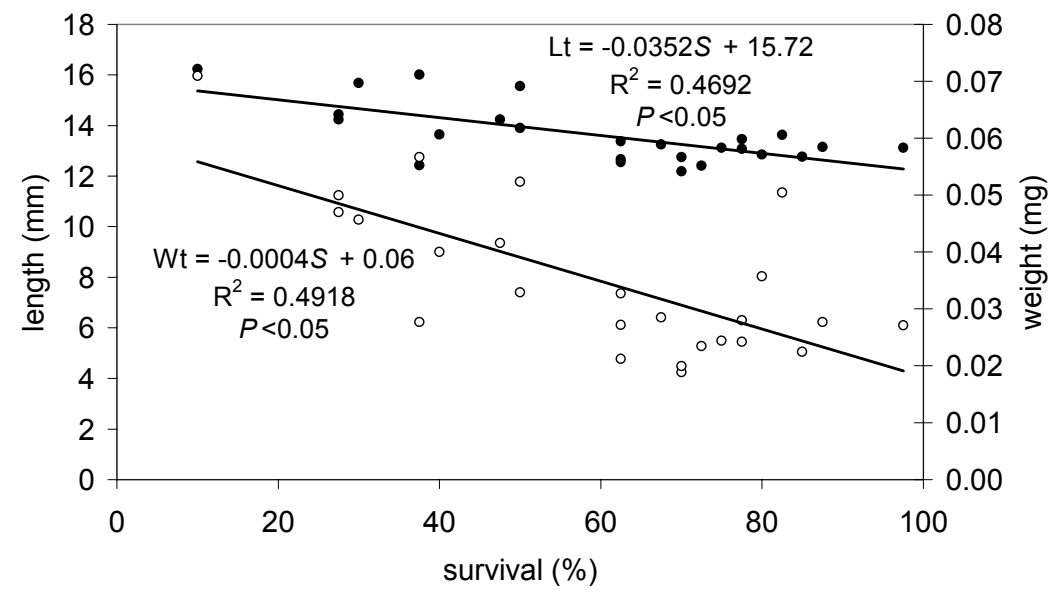

- length $\circ$ weight

Figure 3. Relationship between final survival $(S)$ and length $(\mathrm{Lt})$ or weight $(\mathrm{Wt})$.

Machado et al. (1998) tested a gradual feed transition for fingerlings of pintado, Pseudoplatystoma corruscans, using ground cattle heart and artificial diet, found survival rates close to $80 \%$ after 25 days. In a study with the same species, Smermam et al. (2002) described a survival rate of $6.5 \%$ when larvae were fed zooplankton and blood meal during the feed transition period.

Results showed that bocudo larvae tend to easily accept artificial diet when submitted to a feed transition period, without impairing either performance or survival, thus reducing costs in the larval rearing phase of the species. However, even with satisfactory survival rates when compared to other carnivorous species, cannibalism among larvae was observed during the experimental period, therefore suggesting that the results can be enhanced with new studies aiming to improve the management practices in larval rearing and, consequently, reducing larval cannibalism.

\section{ACKNOWLEDGMENTS}

The authors thank Tractebel Energia for the financial support and $\mathrm{CNPq}$ for the scholarship granted to the first author. 


\section{REFERENCES}

APPELBAUM, S.; VAN DAMME, P. The feasibility of using exclusively artificial dry feed for the rearing of Israeli Clarias gariepinus (Burchell, 1822) larvae and fry. J. Appl. Ichthyol., v.4, p.105-110, 1988.

BALDISSEROTTO, B. (Ed). Fisiologia de peixes aplicada à piscicultura. Santa Maria: UFSM, 2002. 212p.

BARCELLOS, L.G.; KREUTZ, L.C.; QUEVEDO, R.M. et al. Nursery rearing of jundiá, Rhamdia quelen (Quoy \& Gaimard), in cages: cage type, stocking density and stress response to confinement. Aquaculture, v.232, p.383-394, 2004.

BERGOT, P. Élevage larvaire de la carpe commune (Cyprinus carpio L.): alimentation artificielle. In: BILLARD, R.; MARCEL, J. (Eds). Aquaculture of cyprinids. Paris: INRS, 1986. p. 227-234.

BERGOT, P.; CHARLON, N.; DURANTE, H. The effect of compound diets feeding on growth and survival of coregonid larvae. Arch. Hidrobiol. Beich., v.22, p.265-272, 1986.

CHARLON, N.; DURANTE, H.; ESCAFFRE, A.M. et al. Alimentation artificielle dês larves de carpe (Cyprinus carpio L.). Aquaculture, v.54, p.83-88, 1986.

BOYD, C.E. (Ed). Water quality in warmwater fish ponds. Alabama: Craftmaster, 1979. 359p.

CYRINO, J.E.P.; KUBITZA, F. Dietas para condicionamento alimentar do tucunaré Cichla sp. Sci. Agric., v.60, p.609-613, 2003.

DABROWSKI, K.; TAKASHIMA, F.; STRÜSSMANN, C. et al.. Rearing of coregonid larvae with live and artificial diets. Bull. Jpn. Soc. Sci. Fish, v.52, p.23-30, 1986.

FEIDEN, A.; REIDEL, A.; SIGNOR, A. Desenvolvimento do jundiá, Rhamdia quelen (Pisces, Pimelodidae), cultivado em tanques-rede num reservatório do rio Iguaçu, Paraná. In: CONGRESSO BRASILEIRO DE ENGENHARIA DE PESCA, 12., 2001, Foz do Iguaçu. Anais... Foz do Iguaçu, 2001.

FERMIN, A.C.; BOLIVAR, M.E.C. Larval rearing of the Philippine freshwater catfish, Clarias macrochepalus (Gunther), fed live zooplankton and artificial diet: a preliminary study. Isr. J. Aquac., v.43, p.87-94, 1991.

HOGENDOORN, H. Controlled propagation of the African catfish, Clarias lazera $(\mathrm{C} \& \mathrm{~V})$ III. Feeding and growth of fry. Aquaculture, v.21, p.233-241, 1980.

JOHANSSON, O.; WEDBORG, M. The ammonia-ammonium equilibrium in seawater at temperatures between 5 and $25^{\circ} \mathrm{C}$. J. Solut. Chem., v.9, p.37-44, 1980.

KERDCHUEN, N.; LEGENDRE, M. Larval rearing of an African catfish, Keterobranchus longifilis (Teleostei, Clariidae): a comparison between natural and artificial diet. Aquat. Living Res., v.7, p.247-253, 1994.

KNUD-HANSEN, C.F.; BATTERSON, T.R.; MCNABB, C.D. et al. Hatchery techniques for egg and fry production of Clarias batrachus (Linnaeus). Aquaculture, v.89, p.9-19, 1990.

KOLKOVSKI, S.; KOVEN, W.; TANDLER, A. The mode of action of Artemia in enhancing utilization of microdiet by gilthead seabream Sparus aurata larvae. Aquaculture, v.155, p.193205, 1997.

KURUNUMA, K.; FUKUSHO, K. (Eds). Rearing of marine fish larvae in Japan. Ottawa: IDCR, 1984. 109p.

LAVENS, P.; SORGELOOS, P. (Eds). Manual on the production and use of live food for aquaculture. Rome: FAO, 1996. 295p. (FAO Fisheries Technical Paper 361)

LUCZYNSKI, M.; MAJKOWSKI, P.; BARDEGA, R. et al. Rearing of larvae of four coregonid species using dry and live food. Aquaculture, v.56, p.179-185, 1986.

LUZ, R.K.; ZANIBONI FILHO, E. Utilização de diferentes dietas na primeira alimentação do mandi-amarelo (Pimelodus maculatus, Lacépède). Acta Scient., v.23, p.483-489, 2000.

MACHADO, J.H.; DEL CARRATORE, C.R.; GAROSSINO, A.P.R. et al. Treinamento alimentar para aceitação de rações artificiais em alevinos de pintado (Pseudoplatystoma coruscans). In: AQÜICULTURA BRASIL, 1998, Recife. Anais... Recife, 1998. v.2, p.101107.

MEURER, S.; ZANIBONI FILHO, E. O suruvi Steindachneridion scripta Ribeiro, 1918, como 
espécie alternativa para a piscicultura sul brasileira. In: SIMPÓSIO BRASILEIRO DE AQÜICULTURA, 11., 2000, Florianópolis. Anais... Florianópolis, 2000.

ORTEGA, A.G. Valor nutricional de los quistes de Artemia y su uso como fuente de proteína en dietas artificiales para larvas de peces. In: CRUZ-SUÁREZ, L.E.; RICQUE-MARIE, D.; TAPIA-SALAZAR, M. et al. (Eds). Avances en nutrición acuícola. Yucatán: Mérida, 2000. p.287-299.

RINGUELET, R.A.; ARAMBURÚ, R.A.; ARAMBURÚ, A.A. (Ed). Los peces argentinos de agua dulce. La Plata: Comisión de Investigación Científica, 1967. 602p.

SCHÜTZ, J.H.; NUÑER, A.P.O.; ZANIBONI FILHO, E. et al. Avaliação do desempenho e da sobrevivência de pós-larvas de suruvi, Steindachneridion scripta (Pimelodidae), em diferentes salinidades. In: SIMPÓSIO BRASILEIRO DE AQÜICULTURA, 11., 2000, Florianópolis. Anais... Florianópolis, 2000.

SIPAÚBA-TAVARES, L.H. (Ed). Limnologia aplicada à aqüicultura. Jaboticabal: FUNEP, 1994. 72p.

SIPAÚBA-TAVARES, L.H.; ROCHA, O. (Ed). Produção de plâncton (fitoplâncton $e$ zooplâncton) para alimentação de organismos aquáticos. São Carlos: Rima, 2003. 106p.

SMERMAN, W.; CASTRO, J.G.D.; TOLEDO, J.J. et al. Larvicultura de Pintado (Pseudoplatystoma $\mathrm{sp}$ ) em Alta Floresta - Mato Grosso. Rev. Biol. Cienc. Terra, v.2, 2002.
Available at $<$ http://www.uepb.edu.br/eduep/rbct/sumarios/pd f/larvicultura.pdf $>$ acessado em 18 mai. 2006.

UYS, W.; HECHT, T. Evaluation and preparation of an optimal dry feed for the primary nursing of Clarias gariepinus larvae (Pisces, Clariidae). Aquaculture, v.47, p.173183, 1985.

VILLEGAS, C.T. The effects on growth and survival of feeding water fleas (Moina macrocopa Straus) and rotifers (Brachionus pricatilis) to milkfish (Chanos chanos Forsskal) fry. Isr. J. Aquac., v.42, p.10-17. 1990.

VINATEA, L.A. (Ed). Princípios químicos de qualidade de água em aqüicultura: uma revisão para peixes e camarões. Florianópolis: UFSC, 1997. 166p.

WEINGARTNER, M.; ZANIBONI FILHO, E. Efeito de fatores abióticos na larvicultura de pintado amarelo Pimelodus maculatus (Lacépède, 1803): salinidade e cor de tanque. Acta Scient., v.26, p.151-157, 2004.

ZANIBONI FILHO, E.; BARBOSA, N.D.C. Priming hormone administration to induce spawning of some Brazilian migratory fish. Rev. Bras. Biol., v.56, p.655-659, 1996.

ZAR, J.H. (Ed). Biostatistical analysis. 3.ed. New Jersey: Prentice Hall, 1996. 662p.

ZAVALA-CAMIN, L.B. Introdução aos estudos sobre alimentação natural em peixes. Maringá: EDUEM, 1996. 129p. 